RISUS - Journal on Innovation and Sustainability ISSN 2179-3565

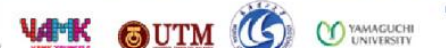

转
RISUS - Journal on Innovation and Sustainability volume 11, número 3 - 2020

ISSN: $2179-3565$

Editor Científico: Arnoldo José de Hoyos Guevara Editor Assistente: Rosa Rizzi

Avaliação: Melhores práticas editoriais da ANPAD

\title{
APPLICATION OF ENTROPY BASED TOPSIS IN ANALYSIS OF SUSTAINABILITY PERFORMANCE OF SRI LANKA HOTELS
}

Aplicação da TOPSIS baseada em entropia na análise do desempenho de sustentabilidade de Sri Lanka Hotels

\author{
PR Weerathunga ${ }^{1,2}$, Cheng Xiaofang ${ }^{1}$, WHMS Samarathunga ${ }^{2},{ }^{3}$, KMMCB Kulathunga $^{1}$ \\ ${ }^{1}$ School of Management, Wuhan University of Technology, Wuhan, P.R. China, 430070 \\ ${ }^{2}$ Faculty of Management Studies, Rajarata University of Sri Lanka, Mihintale, Sri Lanka \\ ${ }^{3}$ School of Tourism, Sichuan University, Chengdu, P.R. China; \\ E-mail: weerathungaroshan@gmail.com,cxf2010611@163.com, \\ maduranga99a@gmail.com, manoj.sus1@gmail.com
}

\begin{abstract}
Sustainability is the limelight of many industries, especially in developing countries. In the hospitality industry, in particular, sustainability plays a pivotal role since it contributes immensely to the economy of a country. However, the hospitality industry is increasingly facing various challenges due to the uncertainty and instability in the business environment. Thus, the central focus of this study is to evaluate the sustainability performance of Sri Lankan hotels industry. For this purpose, 25 hotels were selected from the hotels listed in the Colombo Stock Exchange (CSE). In order to determine the sustainability performance of the selected hotel, we identified 18 indicators that represent the economic, environmental, and social and governance sustainability. Then, we developed a multidimensional sustainability performance index system and using entropy-based TOPSIS, the values of the individual indicators were aggregated. Eventually, we rank the hotels based on the TOPSIS scores, which represent the sustainability performance of hotels. The resulted TOPSIS scores reveal that the Sri Lanka hotels' sustainable performance is moderately high. This indicates that there is a growing tendency to adopt more sustainable practices among hotels companies in Sri Lank. Recently, stakeholders in the state and private sector have paid much attention to the tourism industry because it has tremendous potential and many prospects, and the same is reflected in our results. While we are providing important implications for managers and policymakers, our findings urge the hotels with a lowlevel sustainability performance to go for more sustainable practices.
\end{abstract}

Keywords: Sustainability performance, Hotel industry, Entropy-based TOPSIS, Sri Lanka.

\author{
ACEITO EM: 10/03/2020 \\ PUBLICADO: 30/09/2020
}




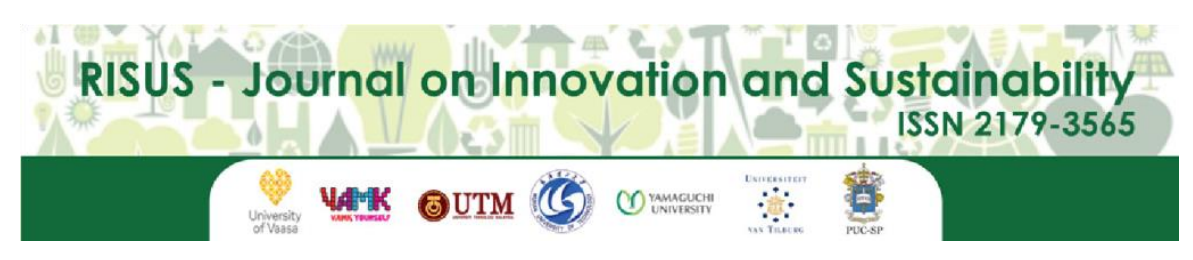

RISUS - Journal on Innovation and Sustainability volume 11, número 3 - 2020

ISSN: $2179-3565$

Editor Científico: Arnoldo José de Hoyos Guevara Editor Assistente: Rosa Rizzi

Avaliação: Melhores práticas editoriais da ANPAD

\title{
APLICAÇÃO DA TOPSIS BASEADA EM ENTROPIA NA ANÁLISE DO DESEMPENHO DE SUSTENTABILIDADE DE SRI LANKA HOTELS
}

\author{
Application of entropy based TOPSIS in analysis of sustainability performance of Sri Lanka Hotels
}

\author{
PR Weerathunga ${ }^{1,2}$, Cheng Xiaofang ${ }^{1}$, WHMS Samarathunga ${ }^{23},{ }^{3}$, KMMCB Kulathunga $^{1}$ \\ ${ }^{1}$ School of Management, Wuhan University of Technology, Wuhan, P.R. China, 430070 \\ ${ }^{2}$ Faculty of Management Studies, Rajarata University of Sri Lanka, Mihintale, Sri Lanka \\ ${ }^{3}$ School of Tourism, Sichuan University, Chengdu, P.R. China; \\ E-mail: weerathungaroshan@gmail.com,cxf2010611@163.com, \\ maduranga99a@gmail.com,manoj.susl@gmail.com
}

\section{RESUMO}

A sustentabilidade é o centro das atenções de muitas indústrias, especialmente nos países em desenvolvimento. No setor de hospitalidade, em particular, a sustentabilidade desempenha um papel fundamental, pois contribui imensamente para a economia de um país. No entanto, a indústria da hospitalidade enfrenta cada vez mais vários desafios devido à incerteza e instabilidade no ambiente de negócios. Assim, o foco central deste estudo é avaliar o desempenho de sustentabilidade da indústria hoteleira do Sri Lanka. Para o efeito, foram seleccionados 25 hotéis entre os hotéis listados na Bolsa de Valores de Colombo (CSE). Para determinar o desempenho de sustentabilidade do hotel selecionado, identificamos 18 indicadores que representam a sustentabilidade econômica, ambiental e social e de governança. Em seguida, desenvolvemos um sistema de índice de desempenho de sustentabilidade multidimensional e usando o TOPSIS baseado em entropia, os valores dos indicadores individuais foram agregados. Por fim, classificamos os hotéis com base nas pontuações TOPSIS, que representam o desempenho de sustentabilidade dos hotéis. As pontuações TOPSIS resultantes revelam que o desempenho sustentável dos hotéis do Sri Lanka é moderadamente alto. Isso indica que há uma tendência crescente de adoção de práticas mais sustentáveis entre as empresas hoteleiras do Sri Lanka. Recentemente, as partes interessadas no estado e no setor privado têm prestado muita atenção à indústria do turismo porque ela tem um enorme potencial e muitas perspectivas, e o mesmo se reflete em nossos resultados. Embora estejamos fornecendo implicações importantes para gerentes e formuladores de políticas, nossas descobertas incentivam os hotéis com desempenho de sustentabilidade de baixo nível a buscar práticas mais sustentáveis.

Palavras-chave: Desempenho em sustentabilidade, Hotelaria, TOPSIS baseado em entropia, Sri Lanka. 


\section{INTRODUCTION}

Despite the recent downturn, the tourism industry is the most vibrant and robust sector in the Sri Lankan economy, with the exponential growth in the number of visitors arriving and the burgeoning foreign exchange earnings. A satisfactory political and economic stability maintained in the nation after the end of the tragic war of 30 years in 2009 , combined with the increasing reputation of the Island as a popular tourist destination, has caused the growth of the tourism industry at a pace never achieved in history (Jayawardhana, Silva, \& Athauda, 2015; Kularatne, Wilson, Månsson, Hoang, \& Lee, 2019). Over the past decade, the hotel sector has also shown significant growth as an integral of the tourism industry in terms of infrastructure development and level of sophistication. SLTDA report (2017) shows that the number of Tourist Hotels has increased from 245 in 2008 to 401 in 2017. Similarly, No. of rooms has also been tripled during the last decade. Apart from the tourist hotels, the other supplementary establishments which provide the accommodation facility have also increased from 513 units in 2008 to 1693 units in 2017. However, because of high capital investments and increased competition, corporate hotels are more inclined to make profits than to be more socially responsible. Nevertheless, corporate hotels ' obligation goes beyond merely creating profit to take care of their employees, the environment, and the society at large.

At the global level, with the realization of the increasing importance of corporate social responsibility, a growing number of hotels companies have moved towards a value-based stakeholder management approach. Such approach enables the managers to maximize the economic value for all stakeholders- shareholders, employees, creditors, suppliers, customers, and society as a whole- by building a strong coalition of all interest groups surrounding the company (Wagner \& Svensson, 2014). Moreover, the natural and socio-cultural environment being an important aspect of the tourist destination, hotels can gain a competitive advantage by displaying their accountability towards the social an environmental impact of their operations. (Assaf, Josiassen, \& Cvelbar, 2012; Cvelbar \& Dwyer, 2013; Wagner \& Svensson, 2014). Therefore, sustainability performance for the hotel industry is increasingly important.

Given the great emphasis on sustainability performance, the main purpose of our study is to empirically analyse the sustainability performance of Sri Lankan corporate hotel sector. For this purpose, listed hotel companies were selected, and the required data was obtained from annual reports and websites. Sustainability performance of each hotel was determined using the author developed a multidimensional evaluation index. Finally, Hotels are ranked based on the sustainable performance score obtained using one of the popular MultiCriteria Decision-Making approaches (MCDM): Technique for Order Preference by Similarity Ideal Solution (TOPSIS).

\section{EVALUATION OF SUSTAINABILITY PERFORMANCE}

\subsection{Development of sustainability performance evaluation Index}

The crucial stage in developing the Sustainable Performance Evaluation Index is to identify appropriate indicators. Since the company's sustainability performance consists of three dimensions, namely Economic, social and governance, and environmental, the indicators should be drawn to cover all the aspects. Following a comprehensive analysis of sustainability literature and experts' opinion, we recognized eighteen indicators, as shown in Table 1. Moreover, these indicators were divided into two groups as positive contributors and negative contributors. Furthermore, the values for the indicators were determined based on the information disclosed in the annual reports and the official web sites of hotel companies. 
Table 1 Sustainability performance Evaluation Indicators

\begin{tabular}{|c|c|c|c|c|}
\hline Dimension & Indicator & Description & Measurement & Contribution \\
\hline \multirow{12}{*}{$\begin{array}{c}\text { Economic } \\
\text { Sustainability }\end{array}$} & $\mathrm{C} 1$ & Five years' Revenue Growth & $\begin{array}{l}\text { (Revenue t - Revenuet-5)/ } \\
\text { Revenuet-5 }\end{array}$ & Positive \\
\hline & $\mathrm{C} 2$ & Market Share & $\begin{array}{l}\text { Hotel's Revenue/ } \\
\text { Industry Revenue }\end{array}$ & Positive \\
\hline & $\mathrm{C} 3$ & Operational cost to total assets & Cost/ Total Assets & Negative \\
\hline & $\mathrm{C} 4$ & $\begin{array}{l}\text { Amount of donations and charitable } \\
\text { contribution to the total revenue }\end{array}$ & Donation/ Total Assets & Positive \\
\hline & $\mathrm{C} 5$ & $\begin{array}{l}\text { Benefits provided to employees } \\
\text { out of Income earned }\end{array}$ & Staff Cost/ Total Assets & Positive \\
\hline & C6 & $\begin{array}{l}\text { Number of social initiatives to } \\
\text { uplift the living condition of } \\
\text { local community }\end{array}$ & & Positive \\
\hline & $\mathrm{C} 7$ & $\begin{array}{l}\text { Number of Initiatives to promote } \\
\text { education, health, culture etc. }\end{array}$ & & Positive \\
\hline & $\mathrm{C} 8$ & $\begin{array}{l}\text { Number of initiatives to ensure } \\
\text { guests' privacy, health \& safety, } \\
\text { and foods safety }\end{array}$ & $\begin{array}{l}\text { Seven Assessment } \\
\text { Levels on a } 1 \text { to } 7 \text { Scale, } \\
\text { where } 1 \text { is the lowest }\end{array}$ & Positive \\
\hline & $\mathrm{C} 9$ & $\begin{array}{l}\text { Analysis of employees based on } \\
\text { gender, age, and region and } \\
\text { number of initiatives to increase } \\
\text { employee welfare (i.e., occupational health, } \\
\text { training \& education, evaluation, } \\
\text { promotion, and recognition \& rewards) }\end{array}$ & and 7 is the highest & Positive \\
\hline & $\mathrm{C} 10$ & $\begin{array}{l}\text { Number of initiatives taken and discussion } \\
\text { of supply chain management }\end{array}$ & & Positive \\
\hline & $\mathrm{C} 11$ & $\begin{array}{l}\text { Awards and certification in recognition of } \\
\text { the social contribution of the hotel }\end{array}$ & $\begin{array}{l}1 \text { score for each award and } \\
\text { certification }\end{array}$ & Positive \\
\hline & $\mathrm{C} 12$ & $\begin{array}{l}\text { Number of committees related to } \\
\text { governance }\end{array}$ & $\begin{array}{ll}1 & \text { score for } \\
\text { each committee }\end{array}$ & Positive \\
\hline \multirow{3}{*}{$\begin{array}{c}\text { Social and } \\
\text { Governance } \\
\text { Sustainability }\end{array}$} & $\mathrm{C} 13$ & $\begin{array}{l}\text { Number of board of directors' meetings } \\
\text { held during the year }\end{array}$ & $\begin{array}{l}1 \text { score for each board } \\
\text { meeting }\end{array}$ & Positive \\
\hline & $\mathrm{C} 14$ & Gender diversity in the director board & $\begin{array}{l}\text { Ratio of female to male } \\
\text { directors }\end{array}$ & \\
\hline & $\mathrm{C} 15$ & $\begin{array}{l}\text { Method adopted to reduce energy and } \\
\text { water consumption, greenhouse gas } \\
\text { emission and initiative to preserve natural } \\
\text { resources }\end{array}$ & $\begin{array}{l}\text { Seven Assessment } \\
\text { Levels on a } 1 \text { to } 7 \text { Scale, } \\
\text { where } 1 \text { is the lowest and } 7\end{array}$ & Positive \\
\hline \multirow{2}{*}{$\begin{array}{l}\text { Environmental } \\
\text { Sustainability }\end{array}$} & $\mathrm{C} 16$ & $\begin{array}{l}\text { Methods and processes adopted to reuse, } \\
\text { recycle effluents and waste. }\end{array}$ & is the highest & \\
\hline & $\mathrm{C} 17$ & $\begin{array}{l}\text { Awards and certification in recognition of } \\
\text { environmentally friendly operations. }\end{array}$ & $\begin{array}{l}1 \text { score for each award and } \\
\text { certification }\end{array}$ & Positive \\
\hline Other & $\mathrm{C} 18$ & $\begin{array}{l}\text { Level of non-compliance to Law and } \\
\text { regulation related social, economic and } \\
\text { environmental areas }\end{array}$ & $\begin{array}{l}\text { Five Assessment Levels on } \\
\text { a } 1 \text { to } 5 \text { Scale, where } 1 \text { is } \\
\text { the lowest and } 5 \text { is the } \\
\text { highest }\end{array}$ & Negative \\
\hline
\end{tabular}

\subsection{Sustainability performance Score}

Use of Multiple Criteria Decision Making (MCDM) methods-for instance, Analytical Hierarchy Process (AHP) Data Envelopment Analysis (DEA) Technique for Order Performance Similarity to Ideal Solution (TOPSIS) is common in the literature on performance assessment. Hsu (2013) used the TOPSIS technique to suggest an investment analysis model based on different financial ratios. Initially, he selected 21 indicators as economic measurement factors and lowered them using dimension reduction methodology to ten most representative factors. Similarly, Deng, Yeh, \& Willis (2000), Wang (2009), Seçme et al. (2009) used the TOPSIS technique to assess financial and non-financial performance. Number of other researches also used TOPSIS as an MCDM strategy to evaluate and rank financial and non-financial performance of various industries (Bulgurcu, 2013; Chang, Lin, Lin, \& Chiang, 2010; Ertuğrul \& Karakaşoğlu, 2009; Kaynak, Altuntas, \& Dereli, 
2017; Kumar, 2016; Weerathunga, Xiaofan, \& Samarathunga, 2019). In light of the previous studies, the sustainability performance of hotels was evaluated using the TOPSIS method developed by (Hwang \& Yoon,

1981). This method is used for four reasons. First, the logic behind TOPSIS is rational and easily understandable, second the calculation process is straightforward, third TOPSIS allows us to determine the best alternative based on a number of criteria using a simple mathematical process and fourth each criterion can be weighted based on different rationales.

The application of the TOPSIS method need to determine appropriate weights for each criterion considered in sustainable performance evolution process. For this purpose, Entropy method as proposed by Shannon (1948) was used. Entropy method is one of the most popular methods for determining weights for indicators (Hsu, 2013). Employing entropy method needs to follow certain steps as mention below.

Step 1: Normalization of $m \times n$ evaluating matrix.

$$
\mathrm{A}=\left[\mathrm{x}_{\mathrm{ij}}\right]_{\mathrm{Mxn}}
$$

Where,

$\mathrm{m}=$ Number of alternatives, $\mathrm{i}=1,2, \ldots \ldots, \mathrm{m} \mathrm{n}=$ Number of criteria, $\mathrm{j}=1,2, \ldots \ldots ., \mathrm{n}$

$\mathrm{x}_{\mathrm{ij}}=$ the performance indicator of $\mathrm{i}^{\text {th }}$ alternative with respect to $\mathrm{j}^{\text {th }}$ criteria.

The original matrix $\mathrm{A}=\left(x_{i j}\right)$ should be normalized to the evaluation matrix $\mathrm{R}=\left(r_{i j}\right)$, where $r_{i j}$ is the normalized valued of $i^{\text {th }}$ alternative with respect to $j^{\text {th }}$ criteria, and $r_{i j} \in[0,1]$. The initial values can be normalized using one of two methods (Chang et al., 2010)below depending on the nature of the data.

For the positive value:

$$
r_{i j}=\frac{\max _{i} x_{i j}-x_{i j}}{\max _{i} x_{i j}-\min _{i} x_{i j}}
$$

For the negative value:

$$
r_{i j}=\frac{x_{i j}-\min _{i} x_{i j}}{\max _{i} x_{i j}-\min _{i} x_{i j}}
$$

Consequently, we have following normalized evaluation matrix

$$
R=\left[r_{i j}\right]_{m \times n}
$$

Step 2: Calculation of weights for each criterion based on entropy.

Weights can be calculated as follows according to (Chang et al., 2010);

- Compute the $p_{i j}$ values using formula (6)

$$
p_{i j}=-k \frac{X_{i j}}{\sum_{n=1}^{m}} p_{i j}, \ln p_{i j}, \forall j
$$

- computed the $d_{i}$ value using formula (7)

$$
d_{i}=1-E_{j}, \forall j
$$

- Calculated weights $\left(w_{j}\right)$ for each criterion using formula (8). One condition muse be satisfied,

$\sum_{j=1}^{n} w_{j}=1$.

$$
w_{j}=\frac{d_{i j}}{\sum_{j=1}^{n} d_{i j}}, \forall j
$$


Third, we calculated the TOPSIS score for each alternative (hotels) using entropy weights obtained in the in the previous section. TOPSIS score is representative of the best alternative from a set of finite alternatives. The best alternative is decided based on the closeness to the positive ideal solution and farthest to the negative ideal solution.

Following is the procedure for TOPSIS score calculation:

Step 1: Obtain the original matrix as shown in equation (1).

Step 2: Constrict the normalized matrix $\left[r_{\mathrm{ij}}\right] m x n$.

Since

$$
\begin{aligned}
& \text { each } \\
& \text { evaluation }
\end{aligned} r_{i j}=\frac{x_{i j}}{\sqrt{\sum_{n=1}^{m} x_{i j}^{2}}},
$$

data for

contain in

Negative contributors are normalized as:

criteria

original

does not

uniform

dimension,

normalized

using

following

$$
r_{i j}=\frac{\frac{1}{x_{i j}}}{\sqrt{\sum_{n=1}^{m}\left(\frac{1}{x_{i j}}\right)^{2}}},
$$

matrix have

Step 3: The normalized decision matrix $\left[r_{i j}\right]_{m x n}$ is converted to weighted normalized decision procedures matrix as follows.

with Y.-J.Wang (2009) and Y.- J.Wang \& Lee (2007).

in line

$$
V=\left(v_{i j}\right)_{\operatorname{mxn}}=\left[\begin{array}{cccc}
w_{1} r_{11} & w_{2} r_{12} & \ldots & w_{n} r_{1 n} \\
w_{1} r_{21} & w_{2} r_{22} & \ldots & w_{n} r_{2 n} \\
w_{1} r_{31} & w_{2} r_{32} & \ldots & w_{n} r_{3 n} \\
\cdot & \cdot & \ldots & \cdot \\
\cdot & \cdot & \ldots & \cdot \\
\cdot & \cdot & \ldots & \cdot \\
w_{1} r_{m 1} & w_{2} r_{m 3} & \ldots & w_{n} r_{m n}
\end{array}\right]
$$

Where, $w_{j}, j=1,2, \ldots, \mathrm{n}$ is entropy weights for each criteria calculated from equation ( 8 ), and $\sum_{j=1}^{n} w_{j}=1$.

Step 4: Determined the positive ideal solution and negative ideal solution by using equation (12) and (13) respectively.

$$
\begin{aligned}
& A^{+}=\left\{v_{1}^{+}, v_{2}^{+}, \ldots, v_{n}^{+}\right\}=\left\{\left(\max _{i} v_{i} j \mid j \in J\right),\left(\min , v_{i} j \mid j \in J\right)\right\} \\
& A^{-}=\left\{v_{1}^{-}, v_{2}^{-}, \ldots, v_{n}^{-}\right\}=\left\{\left(\max _{i} v_{i} j \mid j \in J\right),\left(\min , v_{i} j \mid j \in J\right)\right\}
\end{aligned}
$$

Step 5: Calculated distance (separate measures) for each company for each period from positive ideal solution, $d_{a}^{+}$and negative ideal solution, $d_{a}^{-}$as follows:

$$
\begin{aligned}
& d_{a}^{+}=\sqrt{\sum\left(v_{a i}^{n}-v_{i}^{+}\right)^{2}}, a=1, \ldots, m, \\
& d_{a}^{-}=\sqrt{\sum_{n=1}^{n}\left(v_{a i}^{n}-v_{i}^{-}\right)^{2}}, a=1, \ldots, m,
\end{aligned}
$$

Step 6: Calculated closeness coefficients for each company for each period separately by using following formula.

$$
C_{i}=\frac{d_{a}^{-}}{d_{a}^{+}+d_{a}^{-}}, a=1 \ldots . ., \mathrm{m}
$$


The calculated value of $c_{i}$ is indicative of multidimensional sustainability performance score for each hotel company in our sample. The higher value of $c_{i}$ indicative of higher sustainability performance whereas lover value of $c_{i}$ indicates lower sustainability performance.

\subsection{Sample and data}

In order to select an appropriate sample of hotels companies for our performance evaluation, the annual reports and the web sites of the all 39 hotels listed under Hotels and Travel sector in the Colombo Stock Exchange at the year-end 31st December 2018 were analyzed. This process allows us to identify 25 hotels that match with evaluation criteria in the study. The rest of the hotels were excluded from the analysis since they have not disclosed sufficient information related to their sustainable performance. The information required for performance analysis were extracted from both web sites and the annual reports published at the end of 2017/2018 financial year.

\section{RESULTS}

Table 3 presents the sustainability performance scores and the respective ranks for each hotel in our analysis. The performance scores are calculated using TOPSIS method. Two different methods - entropy weights, equal weights- were used to determine the weights for the selected criteria in each dimension of sustainability performance. The process of determining entropy weights are presented in equations (1) to (7). By equations (8) to (15), the TOPSIS scores were obtained.

Table 3 Sustainability Performance Score and Respective Ranks of the Hotels

\begin{tabular}{cccccc} 
Hotel & $\begin{array}{c}\text { Entropy Weights } \\
\text { Score }\end{array}$ & Rank & Hotel & $\begin{array}{c}\text { Equal Weights } \\
\text { Score }\end{array}$ & Rank \\
\hline Hotel A & 0.710 & 1 & Hotel A & 0.758 & 1 \\
Hotel B & 0.657 & 4 & Hotel B & 0.674 & 5 \\
Hotel C & 0.651 & 5 & Hotel C & 0.680 & 4 \\
Hotel D & 0.391 & 21 & Hotel D & 0.474 & 22 \\
Hotel E & 0.462 & 15 & Hotel E & 0.546 & 13 \\
Hotel F & 0.434 & 17 & Hotel F & 0.551 & 12 \\
Hotel G & 0.585 & 7 & Hotel G & 0.499 & 19 \\
Hotel H & 0.409 & 19 & Hotel H & 0.514 & 17 \\
Hotel I & 0.528 & 10 & Hotel I & 0.540 & 15 \\
Hotel J & 0.691 & 2 & Hotel J & 0.743 & 2 \\
Hotel K & 0.169 & 25 & Hotel K & 0.195 & 25 \\
Hotel L & 0.434 & 16 & Hotel L & 0.542 & 14 \\
Hotel M & 0.539 & 9 & Hotel M & 0.523 & 16 \\
Hotel N & 0.411 & 18 & Hotel N & 0.509 & 18 \\
Hotel O & 0.367 & 23 & Hotel O & 0.421 & 23
\end{tabular}




$\begin{array}{lccccc}\text { Hotel P } & 0.515 & 11 & \text { Hotel P } & 0.622 & 7 \\ \text { Hotel Q } & 0.563 & 8 & \text { Hotel Q } & 0.591 & 9 \\ \text { Hotel R } & 0.327 & 24 & \text { Hotel R } & 0.401 & 24 \\ \text { Hotel S } & 0.491 & 12 & \text { Hotel S } & 0.611 & 8 \\ \text { Hotel T } & 0.468 & 13 & \text { Hotel T } & 0.567 & 11 \\ \text { Hotel U } & 0.408 & 20 & \text { Hotel U } & 0.481 & 21 \\ \text { Hotel V } & 0.386 & 22 & \text { Hotel V } & 0.483 & 20 \\ \text { Hotel W } & 0.464 & 14 & \text { Hotel W } & 0.572 & 10 \\ \text { Hotel X } & 0.664 & 3 & \text { Hotel X } & 0.716 & 3 \\ \text { Hotel Y } & 0.621 & 6 & \text { Hotel Y } & 0.641 & 6\end{array}$

According to the results presented in Table 3, 11 hotels have TOPSIS score above 0.5 under the entropy weights. When equal weights are used in the weighting process, 18 hotels' scores go beyond 0.5. Both of these results indicate the sustainability performance is in the selected hotel are moderately high. The top three hotels under entropy weights are Hotel A, J, and X having sustainability scores of 0.710, 0,691, and 0.664. The ranking

of these top three hotels is same under the equal weights but with different scores. Practically, these three hotels are the largest hotels in term of size and its operations. They have established the best practices within their companies in order to achieve sustainable development. The analysis of their official websites and annual reports revealed that they have fully adopted the Global Reporting Initiative (GRI) guidelines in disclosing their information to the stakeholders. Moreover, these hotels have been recognized with different awards and certification for their achievements in an effort of sustainable development.

\section{CONCLUSION}

The hotel sector as an integral part of the tourism industry is paramount to the economic growth of Sri Lanka. Therefore, the main aim of this study was to analyze the sustainability performance of the hotel sector in Sri Lanka. Our analysis was carried out using the information disclosed by hotel companies in their annual reports and official websites. In order to identify the commitment of hotels towards sustainable development, first, we developed a sustainable performance evaluation index following previous studies and experts' opinion. We identified 18 indicators that could represent the different dimension of sustainable performance such as economic, environmental, and social and governance. Then, each hotels' annual reports of the financial year 2017/18 and websites were analyzed against the developed sustainability index. Following this process, the initial decision matrix was constructed. We use entropy based TOPSIS in determining the sustainability scores for each hotel. The results of the study indicate that the sustainability performance in selected hotels is moderately high. This may be because of the increased attention of different stakeholders of the tourism industry. Moreover, fierce competition in the hotel industry following the recent tourism boom in the country urge the hotel companies to be more vigilant about their operation. As a result, hotels managers have paid more attention to stakeholder-oriented business practices.

The main contribution of this study is the proposed novel approach to determining the sustainability performance of the hotel industry. Moreover, for the best of our knowledge, this is the first attempt to analyze the sustainability of Sri Lankan hotel industry using such a quantitative approach. This research offers significant perspectives for hotel executives, owners, and other hotel sector stakeholders. According to results, certain hotels have a low level of sustainability performance. These hotels should concentrate more on sustainability practices to level up with their peers. Policymakers should encourage hotels through the development of appropriate strategies to adopt sustainable practices.

\section{REFERENCES}

ASSAF A G, JOSIASSEN, A., CVELBAR, L K. Does Triple Bottom Line Reporting Improve Hotel Performance? [J]. International Journal of Hospitality Management, Pergamon, 2012, 31(2): 596-600.

BULGURCU, B. Financial Performance Ranking of the Automotive Industry Firms in Turkey: Evidence from an Entropy-Weighted Technique [J]. International Journal of Economics and Financial Issues, 2013, 3(4): 844- 
851.

CHANG C-H, LIN J-J, LIN J-H. Domestic Open-end Equity Mutual Fund Performance Evaluation Using Extended TOPSIS Method with Different Distance Approaches [J]. Expert Systems with Applications, 2010, 37(6): 4642-4649.

CVELBAR L K, DWYER L. An Importance-performance Analysis of Sustainability Factors for Long- term Strategy Planning in Slovenian Hotels [J]. Journal of Sustainable Tourism, Taylor \& Francis Group, 2013, 21(3): 487-504.

DENG H, YEH, C-H, WILLIS, R. J. Inter-company Comparison Using Modified TOPSIS with Objective Weights [J]. Computers \& Operations Research, 2000, 27(10): 963-973.

ERTUĞRUL İ, KARAKAŞOĞLU N. Performance Evaluation of Turkish Cement Firms with Fuzzy Analytic Hierarchy Process and TOPSIS Methods [J]. Expert Systems with Applications, 2009, 36(1): 702- 715.

HSU, L-C. Investment Decision Making Using a Combined Factor Analysis and Entropy-based TOPSIS Model [J]. Journal of Business Economics and Management, 2013, 14(3): 448-466.

HWANG C-L, YOON K. Methods for Multiple Attribute Decision Making [G].1981: 58-191.

JAYAWARDHANA, A A K K, SILVA, S de, ATHAUDA, A M T P. Business Strategy, Market Orientation and Sales Growth in Hotel Industry of Ancient Cities in Sri Lanka [J]. Tropical Agricultural Research, 2015, 24(3): 228.

KAYNAK S, ALTUNTAS S, DERELI T. Comparing the Innovation Performance of EU Candidate Countries: An Entropy-based TOPSIS Approach [J]. 2017.

KULARATNE, T, WILSON C, MÅNSSON J. Do Environmentally Sustainable Practices Make Hotels More Efficient? A Study of Major Hotels in Sri Lanka [J]. Tourism Management, Pergamon, 2019, 71: 213-225.

KUMAR, N. Financial Inclusion and its Determinants: Evidence from India [J]. Journal of Financial Economic Policy, 2013, Vol 5, No 1, pp 4-19.

SECME, N.Y, BAYRAKDAROGLU A, KAHRAMAN C. Fuzzy Performance Evaluation in Turkish Banking Sector Using Analytic Hierarchy Process and TOPSIS [J]. Expert Systems with Applications, 2009, 36(9): 11699-11709.

SHANNON C E. A Mathematical Theory of Communication [J]. Bell System Technical Journal, John Wiley \& Sons, Ltd, 1948, 27(3): 379-423.

SRI LANKAN TOURISM AUTHORITY ANNUAL REPORT [G]. Sltda.lk, 2018.

WAGNER B, Svensson G. A Framework to Navigate Sustainability in Business Networks [J]. European Business Review, Emerald Group Publishing Limited, 2014, 26(4): 340-367.

WANG Y-J. Combining Grey Relation Analysis with FMCGDM to Evaluate Financial Performance of Taiwan Container Lines [J]. Expert Systems with Applications, 2009, 36(2): 2424-2432. 
WANG Y-J, LEE H-S. Generalizing TOPSIS for Fuzzy Multiple-criteria Group Decision-making [J]. Computers \& Mathematics with Applications, Pergamon, 2007, 53(11): 1762-1772.

WEERATHUNGA P R, XIAOFAN C, SAMARATHUNGA M. Firm-specific and Contextual Determinants of Sri Lankan Corporate Hotel Performance [J]. International Journal of Economics and Financial Issues, 2019, 9(3): 213-224. 